
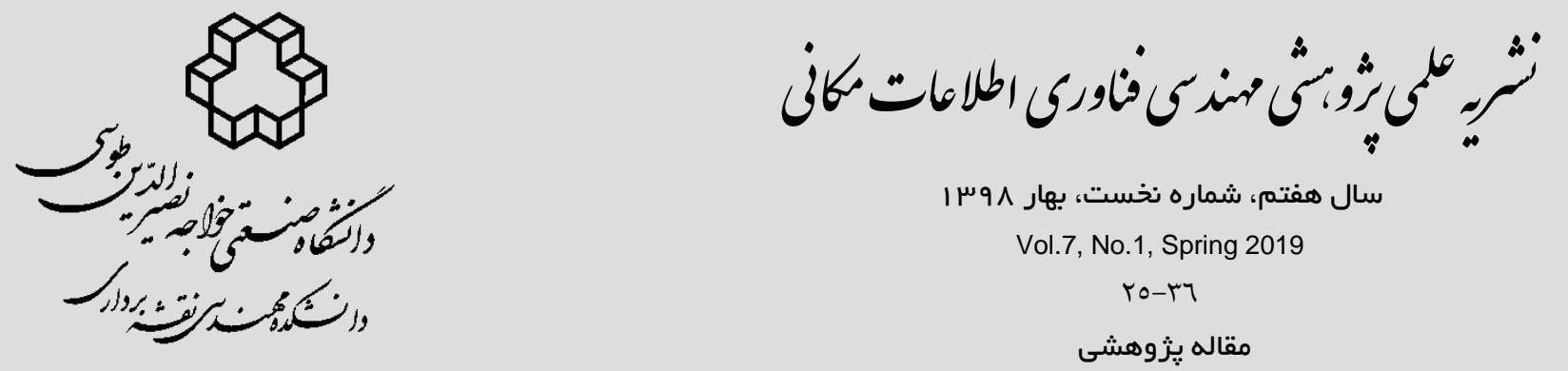

شناسايى مكانهاى انباشت نخالههاى ساختمانى با استفاده از شاخصها و تفاضلهاى طيف بازتابندكى در تصاوير لندست (مطالعه موردى: مناطق شهريار و ملارد)

$$
\text { محمدرضا مباشرى"'، نرَس جعفرى ' }
$$

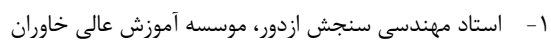

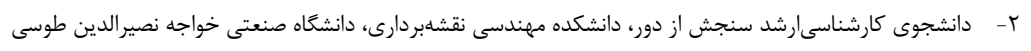

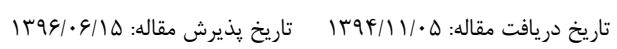

جكکده

براثر يديدههاى طبيعى و فعاليتهاى انسانى تهره زمين همواره دستخوش تغيير مىشود، اطلاع از تغييرات سطحى اهميت بسيار زيـادى

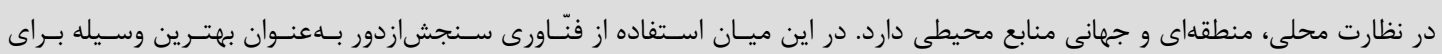

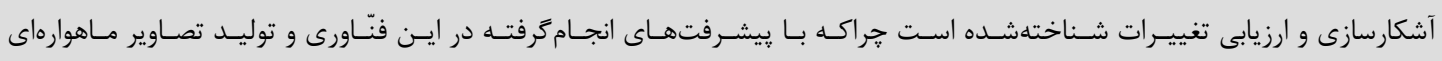

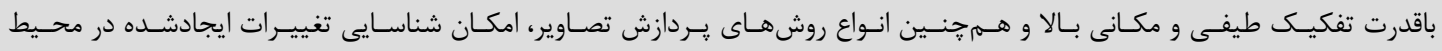

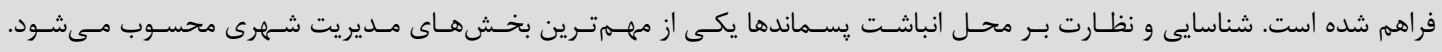

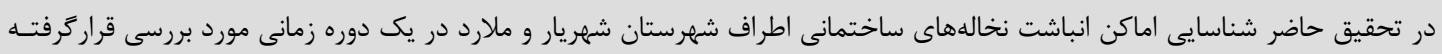

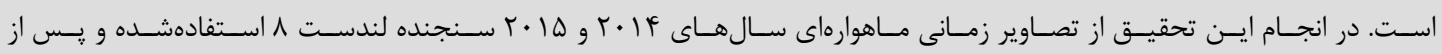

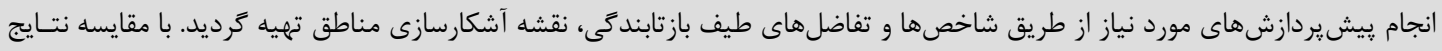

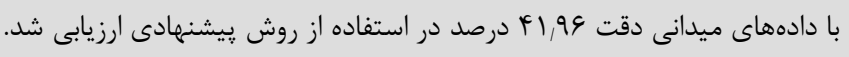

كليد وازهها: آشكارسازى تغييرات، نخالههاى ساختمانى، لندست ^، سنجشاز دور 
غيرقانونى مواد زائد ايجاد كـرده اسـت. افـزايش مقــادير نخالههاى ساختمانى جنـــين موضـوع از قبيـل كمبــود

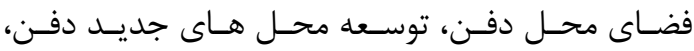

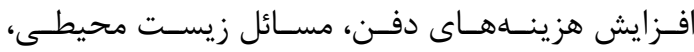

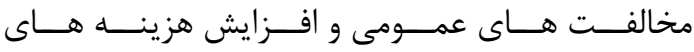

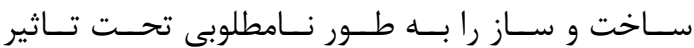
قرار داده است. بنابراين مديريت نخاله هاى سـاختمانى يكى از موضوعات مههم خصوصا در كشـورهاى در حسال

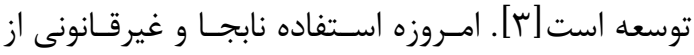
مناطق خالى و نقاط مختلف اطراف شهر براى تخليسهى نخالهاى ساختمانى و از بين رفتن محيط زيست منطقه

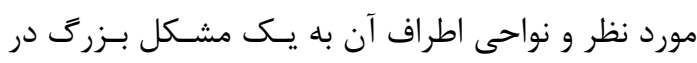
جوامع در حال رشد تبديل شـده اسـت. بـدين منظــور نظارت بر محل هاى تخليـهى نخالـههـاى سـاختمانى و ونال

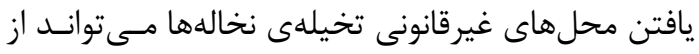

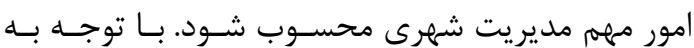

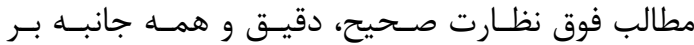

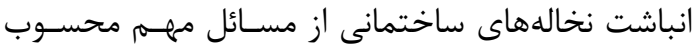

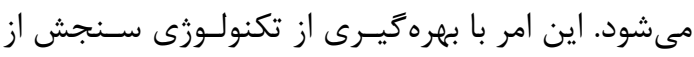
دور بسيار سريعتر، دقيقتر و ارزانتر خواهد بود. سنجش از دور، سيستم اطلاعات جغرافيايى و مدلسازى

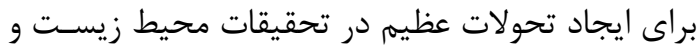

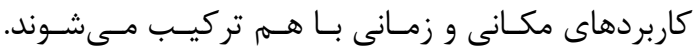

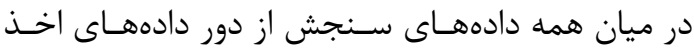

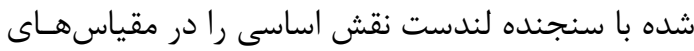

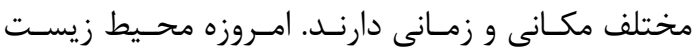
زمينى براى مدلسازى و توصسيف ويزگكىهـاى يوشـش

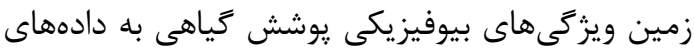

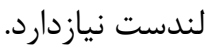
آشكارسازى تغييرات با بهكاركرفتن مجموعـهـ دادهــاى ناي جندزمانى بهمنظور مشخص كردن منـاطقى اسـت كـهـ

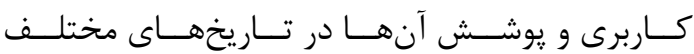

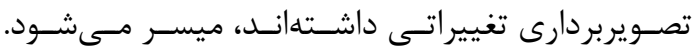

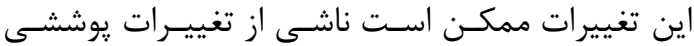

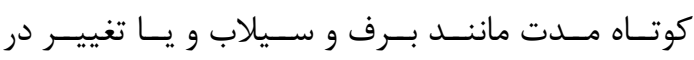

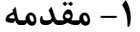

مديريت مواد زائد جامد يكى از مشـكلات عمــده يـيش

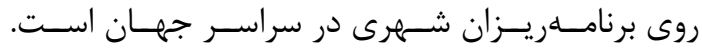
اين مشكل در كشورهاى درحال توسعه شـديدتر اسـت. در اين كشورها برنامهريزى ضعيف، فقدان منابع مـالى و آكاهى كم شهروندان منجر به ضعف مديريت مواد زائسد

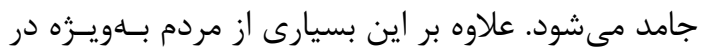

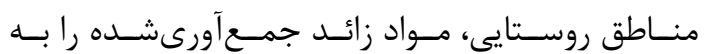

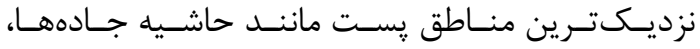

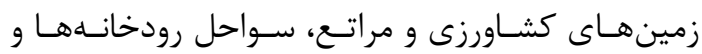

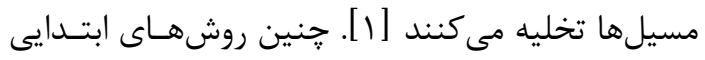
انباشت مواد زائد منجر به آلودحى آبوخاك و هوا شــده

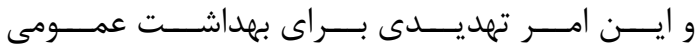

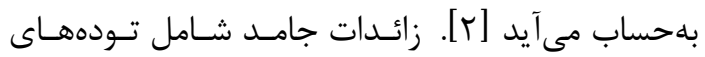
ناهمخون از مواد دور ريخته شده از اجتماعات شهرى و وات التهات

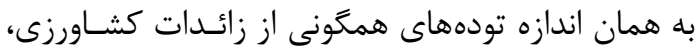
صنعتى و معادن است بخش عمدهاى از مواد زائد جامـد

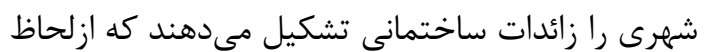

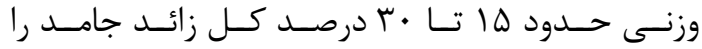
شامل مىشوند [ب].

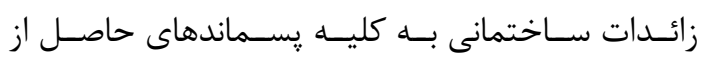
ساختوساز، تخريـب امـاكن، سـاختمانهـاى فرسـوده،

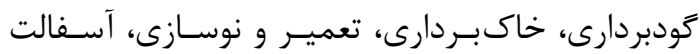

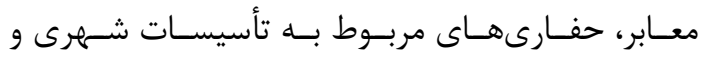

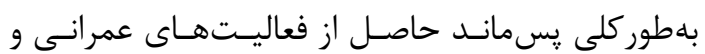

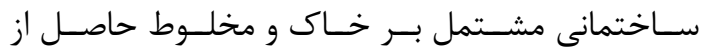

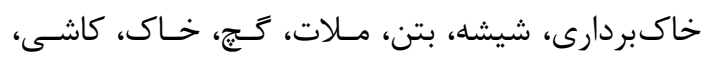

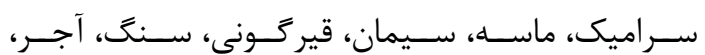
موزاييك، رابيتس، تيرجهى سـقفى، شـيروانى، جـوب و و

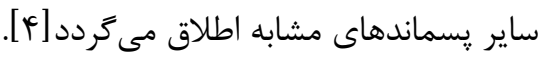

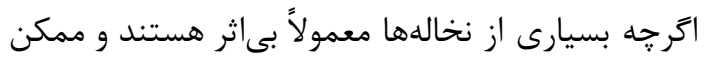
است به اندازمى زائدات خطرناك يا ساير مواد زائد جامد

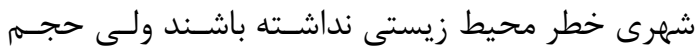

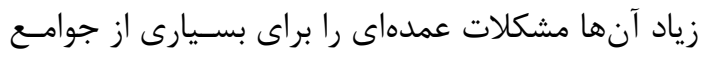

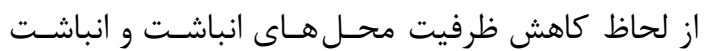




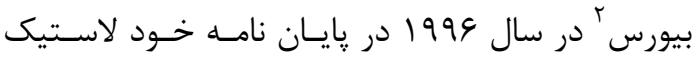

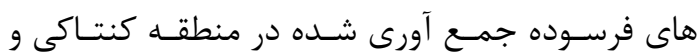

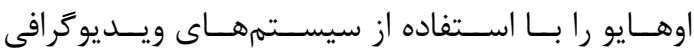

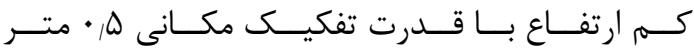

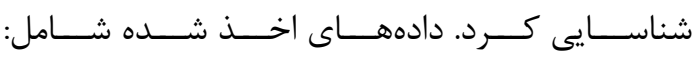
اندازهكيرىهاى طيفى، امضاى طيفى انواع و ماركهـاى

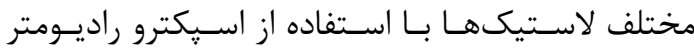

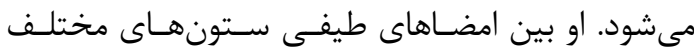
لاستيكها با ارتفـاعهـا و مـاركهـــاى مختلـف، تفـاوت جندانى مشاهده نكـرد. بيـورس تفـاوتهـايى در طيـف

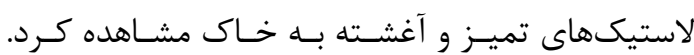

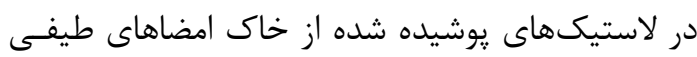

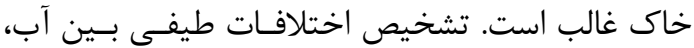

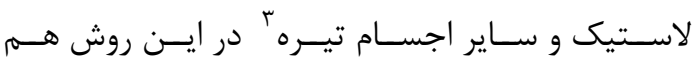

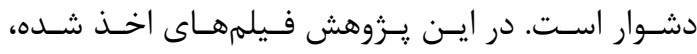

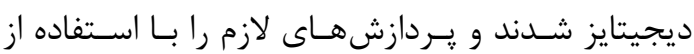

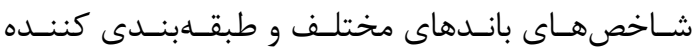
بيشتـرين شـباهت انجـام شـدند. نتـايج در شناسـايى

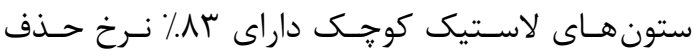
بهعلت وجود تعداد يُيكسل هاى لاستيك خـالص كمى و

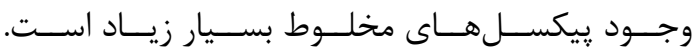

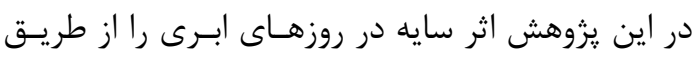

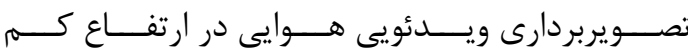
حذف شده است [V]

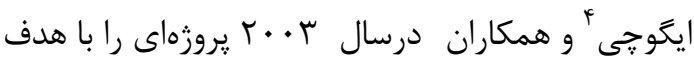

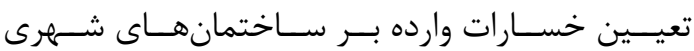

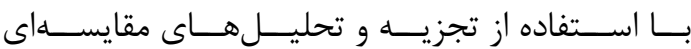

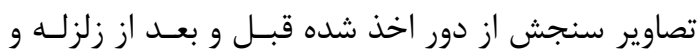

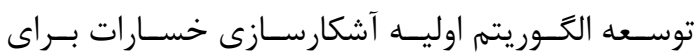

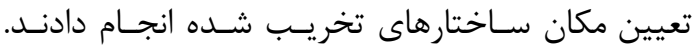
ورودى هاى اين تحقيق دادههاى سـنجندههـاى اسـيات

\footnotetext{
${ }^{2}$ Beavers

${ }^{3}$ Dark Object

${ }^{4}$ Eguchi
}

كاربرى اراضى مانند توسعهى شهرى و تبـديل اراضى كـــ

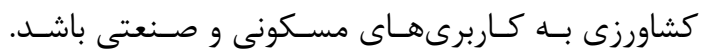

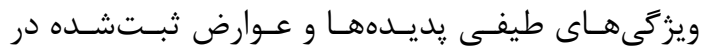
دادههـاى ســنششازدورى، نقـش مهمسى در كشـف و و مدل سازى تغييرات يوشش زمين در اثر دخالت عوامـلـ إدلـ

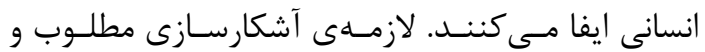
استخراج اطلاعات دقيق از تغييرات يوشش مـورد نظــر،

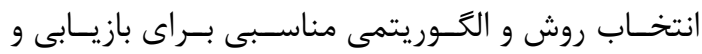
كشف اين تغييرات و داشتن دانش و اطلاعـات كـافى از

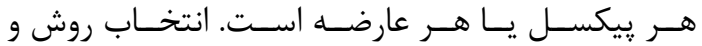

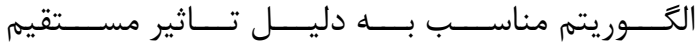

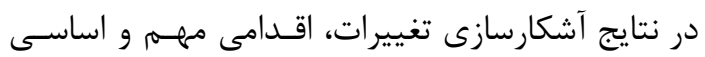
است[ه]. - است

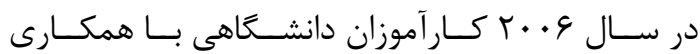

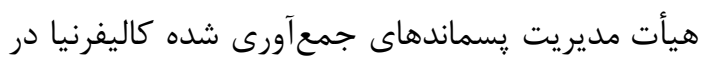
مركز تحقيقات ايمز بامنظور بررسى استفاده از تصـاوير

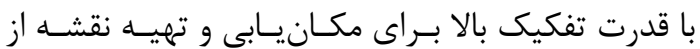

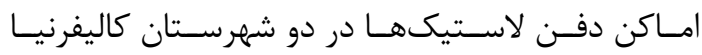

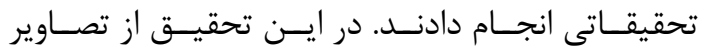
آيكونوس بعلت هزينه كم و قدرت تفكيك مكانى بالا در

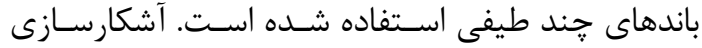
لاستيكهاى فرسـوده نيازمنــد قـدرت تفكيــ طيفى

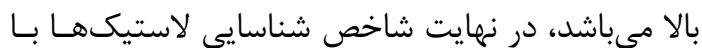

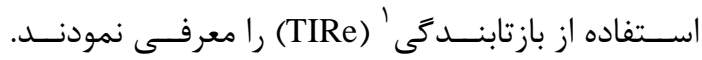

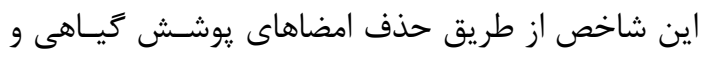

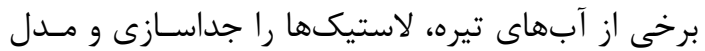

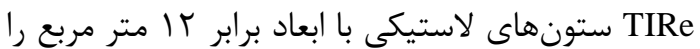
شناسايى مى كند. آشكارسازى لاستيكهاى فرسـوده در

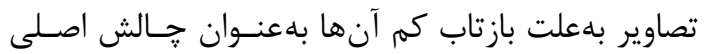

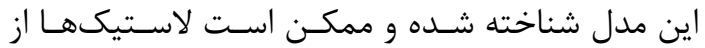

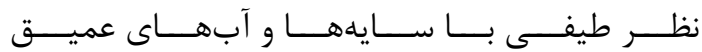
اشتباه كرفته شوند [ع].

${ }^{1}$ Tire identification from reflectance 


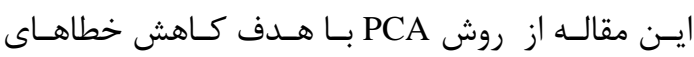

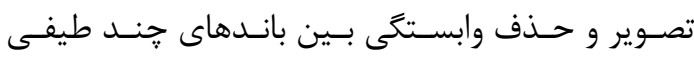

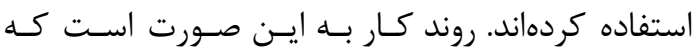
در ابتدا تصاوير اخذ شده مكان مبنا خواهند شد سـيس

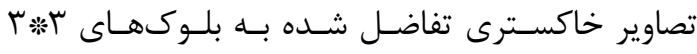
بدون هم يوشانى تقسـيم مسىشـوند و بردارهـاى ويـرن

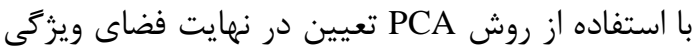

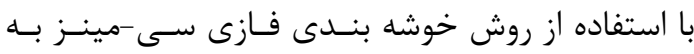

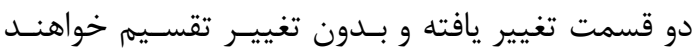
شد. از مزاياى روش ارائهشـده مسىتـوان بــه محاسـبات

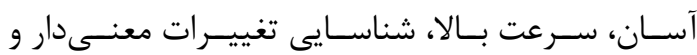

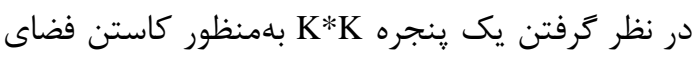

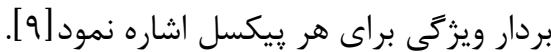
روشهاى كفته شده به بررسى تغييرات سـطحى زمهـين

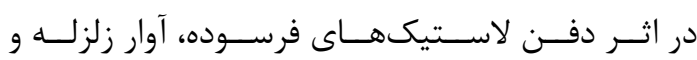

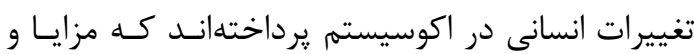

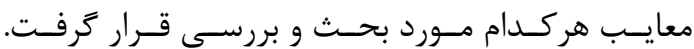

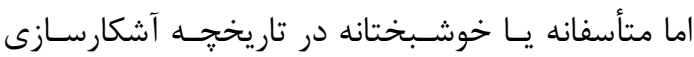

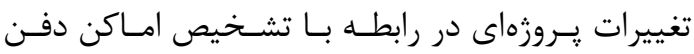
نخالههاى ساختمانى انجام نشده است.

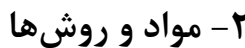

در ايــن قسـمت، منطقــه مــورد مطالعـه و دادههــاى مورد استفاده معرفى مىشوند.

r- (- منطقه مورد مطالعه استان تهران به مركزيت شهر تهران، با وسـعتى حسدود

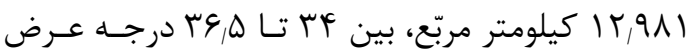
شمالى و •ه تا بهه درجه طول شرقى واقع شـدهاسـت.

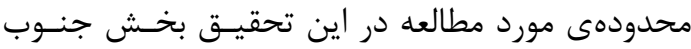
غربى استان تهران در منطقه شهريار و ملارد است. بهدليل حجم بالاى سـاخت و سـازهاى اخيــر و سـاخت شهركهاى اقمارى در اطراف شهر تهران در اين تحقيق

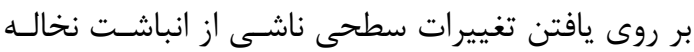

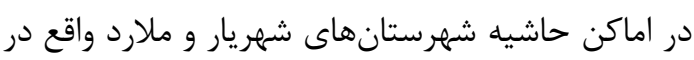

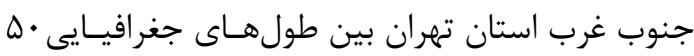

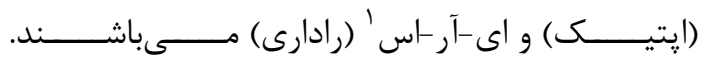
شاخصهاى آشكارسازى تغييرات كه بـر روى دادهــاى آرى קانكروماتيك اسيات مورد بررسـى قـرار ترفـته، شـامل تفاضل ساده بين مقادير شدت و هــم بسـتخى (بلـوكى و

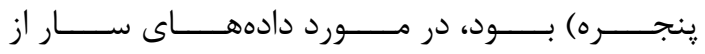
شاخصهاى بيشترى استفاده شـد كـهـ شـامل مقايسـهـ تفاضل ساده بين مقادير شـدت، هـم بسـتخى (بلـوكى و

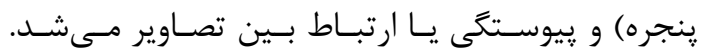
شاخصهاى تغييرات با دادههاى زمينى جمع آورى شده مقايسه مىشود و در نهايت يك مجموعه الكوريته براى

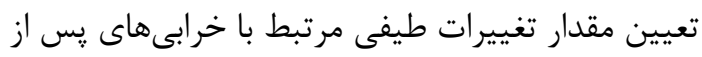

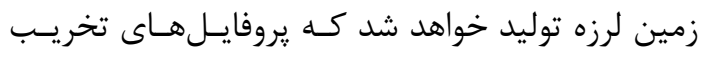

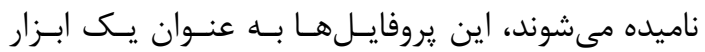
اكتشافى براى نمايش روند تخريب ساختمانها و ميزان

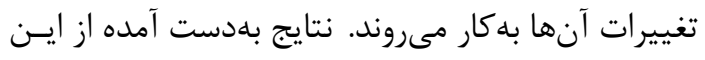
روش بيانكر اين موضوع هستند كه نخالههاى مرتبط بـا بـا

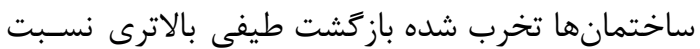

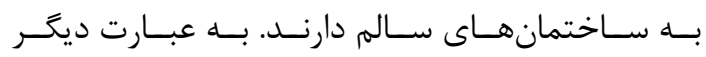
نخالههاى ساختمانى به نسبت خود ساختمانها بازتاب بيشترى دارند]1]].

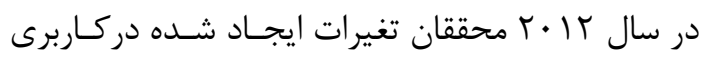

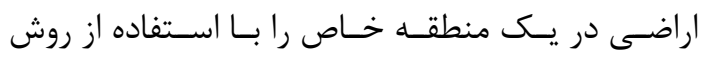

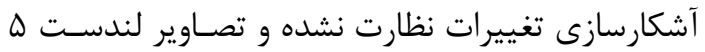

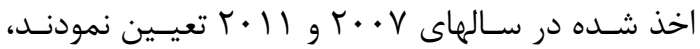

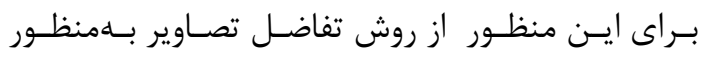

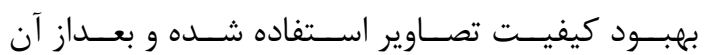

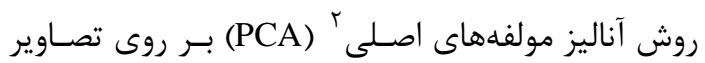

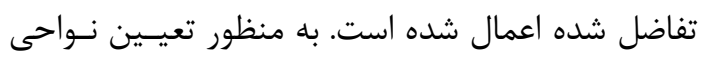

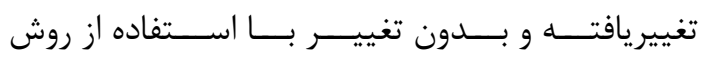

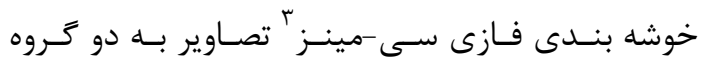
تغيير يافته و بدون تغيير تقسيم ميشـوند. محققــان در

\footnotetext{
${ }^{1}$ ERS

${ }^{2}$ Principle Component Analysis

${ }^{3}$ Fuzzy C-Means
} 
درجه و •له دقيقه شرقى تا اله درجه شـرقى و عـرض له دقيقه شمالى تمركز داده شده است. (شكل ))

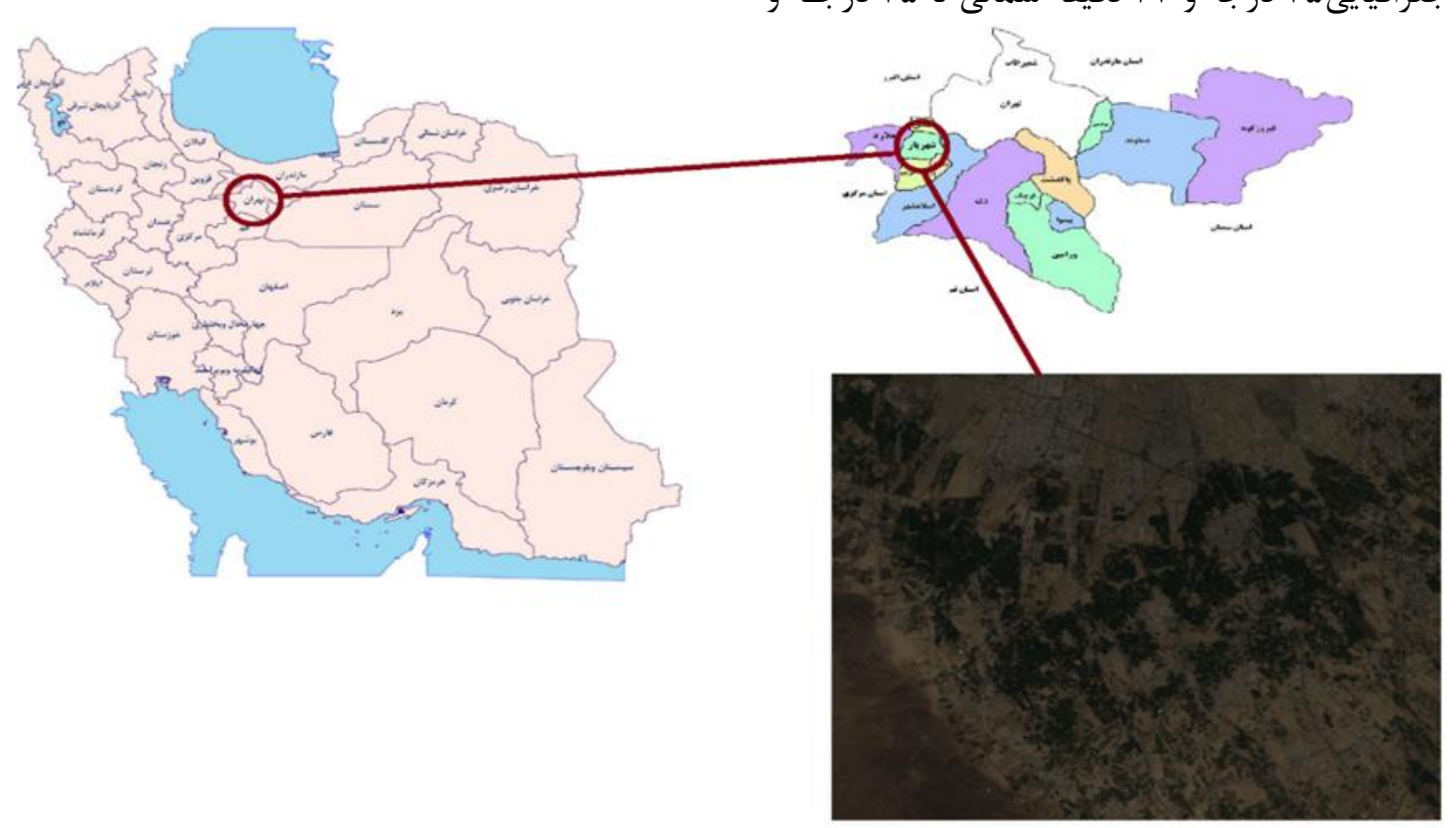

شكل ا: موقعيت مكانى منطقه مورد مطالعه، ناحيه غربى تهران، ايران

r-Y - دادهها مورد استفاده

بررسى اوليه منطقه(شكل )).

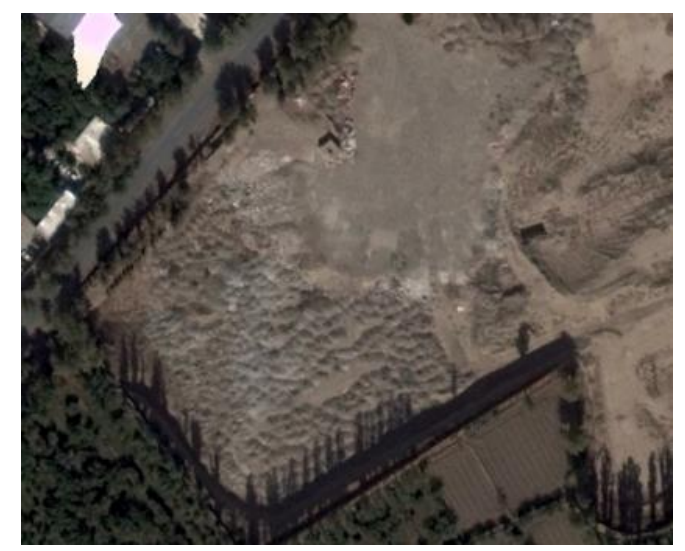

$\varphi$
در اين تحقيق از جهار تروه داده استفاده خواهد شد:

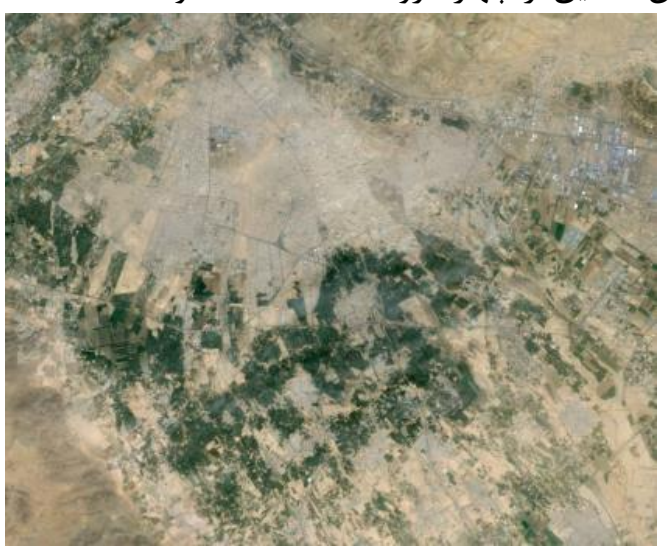

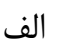

شكل r: تصوير گومَل ارث الف: منطقه مورد مطالعه- ب: يكى از سايتهاى انباشت نخاله

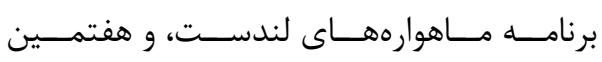

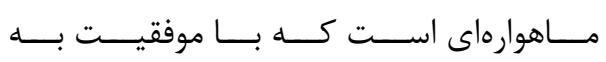

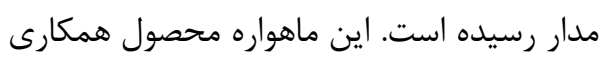

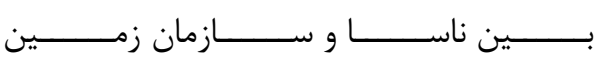

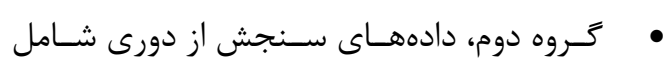

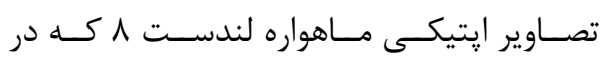

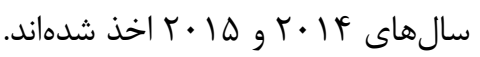

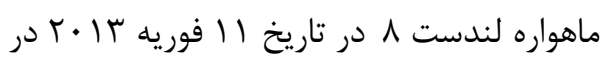

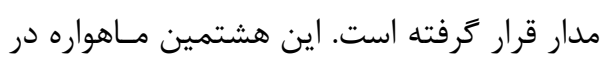


حداقل و حداكثر دمـا، وضـعيت بـارش، ميـزان

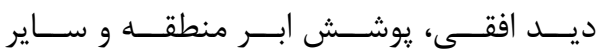

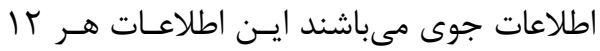

ساعت يكبار برزو رسانى مىشوند.

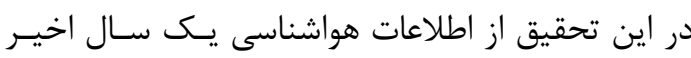

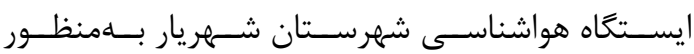

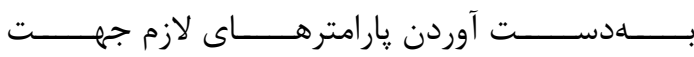

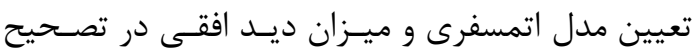
اتمسفرى تصاوير لندست م استفادهشده است.

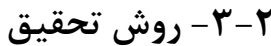

در اين تحقيق بـهـنظـــور بررسى تغييـرات سـطحى و شناسايى اماكن انباشت نخالههاى ساختمانى در بـازئى

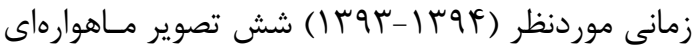

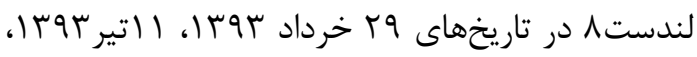

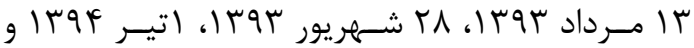

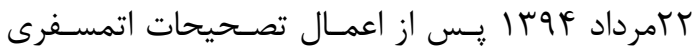

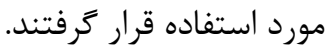

\section{ץ-ץ-1- تصحيح اتمسفرى}

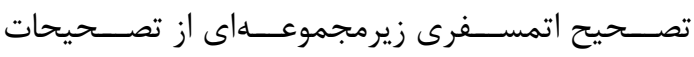

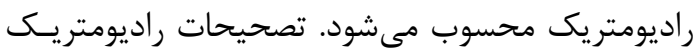
تبديلاتى هستند كه بر دادهها اعمال شــه تـا برخسى از

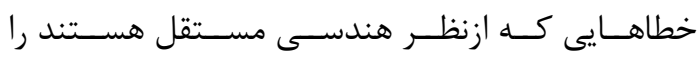

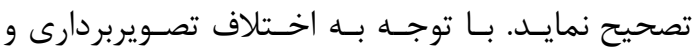
زاويـهـ تـابش خورشــيد در تصـاوير مختلـف در هنـــام

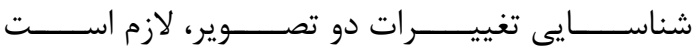

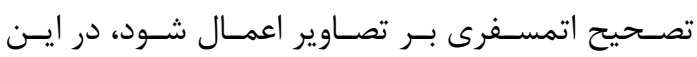
يزوهش فر آيند تصحيح اتمسفرى با استفاده از برنامـهى إنى

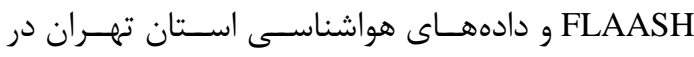

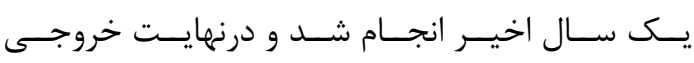
تصحيح اتمسفرى بازتابندگى سطحى عوارض است.

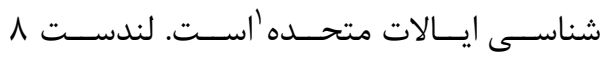

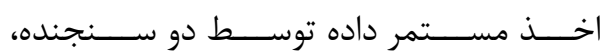

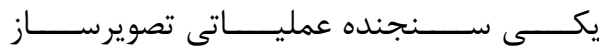

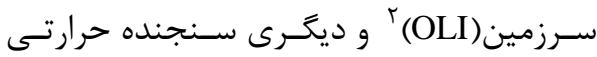

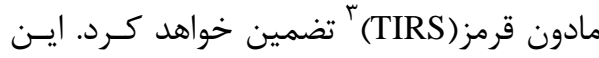
دو سنجنده بـه ترتيـب، اطلاعـات تصـوير را در

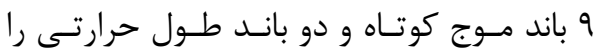
جمع آورى مى كنند.

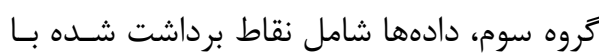

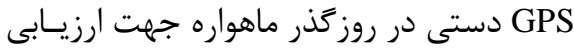

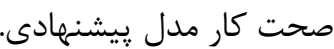

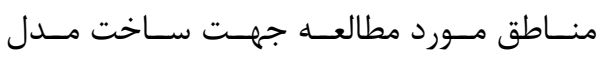
سايتهاى دفن نخالههـاى سـاختمانى در شـهر

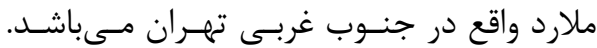

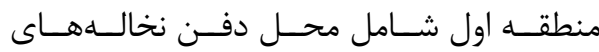
ساختمانى و منطقه دوم شامل نواحى مسكونى،

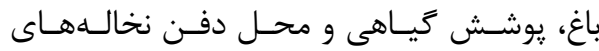
ساختمانى مىباشد. انتخاب دادههاى آموزشى و و

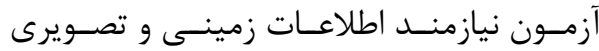

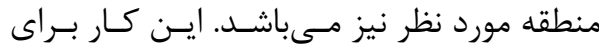

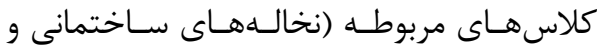
كلاسهاى ديكر شامل تبديل يافتـه بـه خـاى،

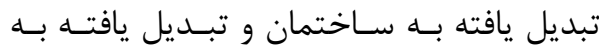
يوشش كياهش) بـا توجـهـ بـه، تفسـير تصـاوير Google earth بازديدهاى زمينى صورت كرفته اسـت. تصـاوير

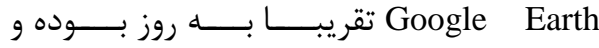

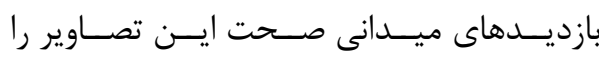

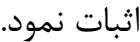
كروه جهارم، دادهاى هواشناسى دادههاى هواشناسى شـامل اطلاعـاتى دربـارهى هرى

${ }^{1}$ USGS

${ }^{2}$ Operational Land Imager

${ }^{3}$ Thermal Infrared Sensor 
محمدرضا مباشرى، نركس جعفرى

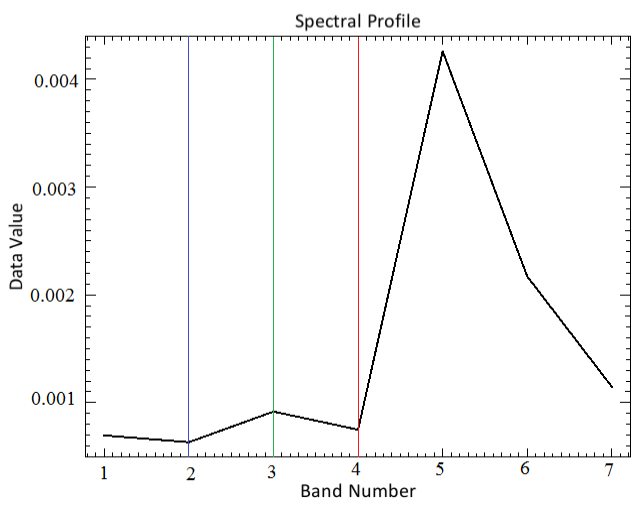

ب

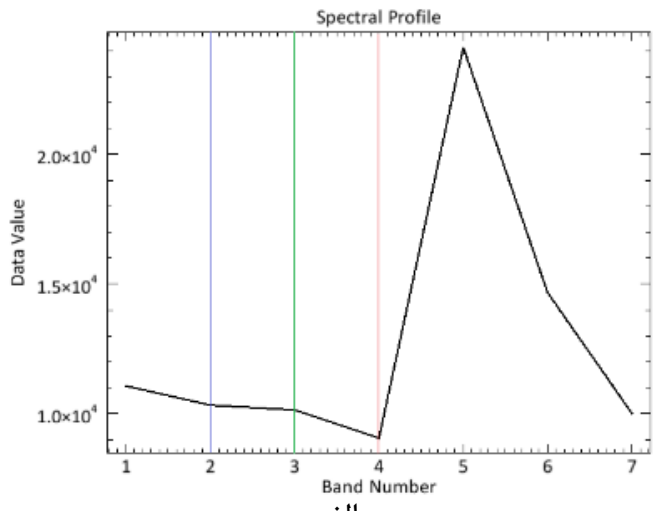

الف

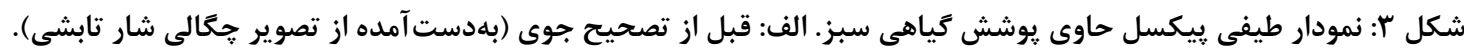

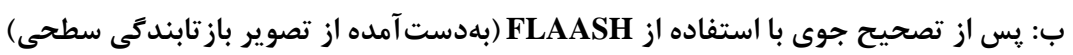

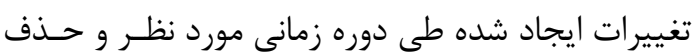

r-r-r- تصحيح هندسى

مناطقى كه از نظر شدت تغييرات كم ارزيابى مىشـوند،

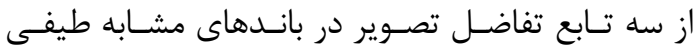
استفاده گرديد. سيس باندهاى تفريقى با استفاده از حد

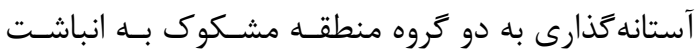

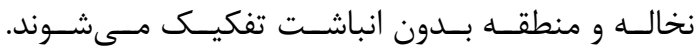

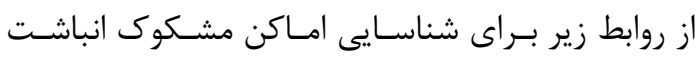
استفاده شده است:

$$
\text { رابطه }
$$

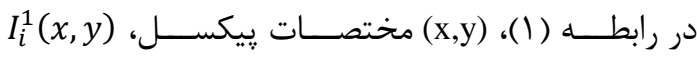

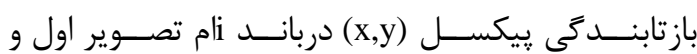

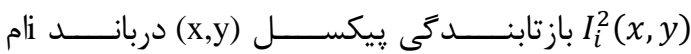
تصوير دوم است. $\hat{\alpha}=\cos ^{-1}\left(\frac{\sum_{i=1}^{n} I_{i}^{2}(x, y) I_{i}^{1}(x, y)}{\left|\bar{I}^{1}(x, y)\right|\left|\bar{I}^{2}(x, y)\right|}\right) \quad$ (Y)

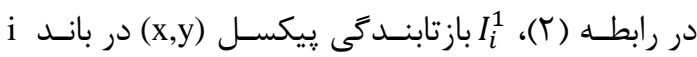

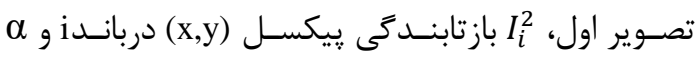

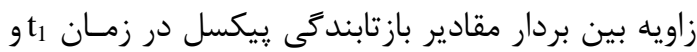
بردار مقادير بازتابندگى ييكسل در زمان $R D=\frac{\left|I_{i}^{2}(x, y)-I_{i}^{1}(x, y)\right|}{I_{i}^{1}(x, y)+\varepsilon} \times 100$ رابطه (r) در رابطه (ץ)، Iri $I_{i}^{1}$

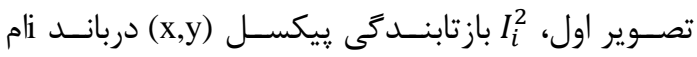

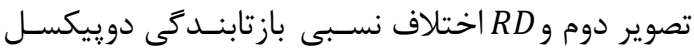

اين تصاوير زمسين مرجـع شـده در سيسـتم مختصـات

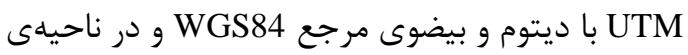

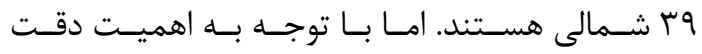
تصحيح هندسى بر صحت نتايج آشكارسـازى تغييـرات

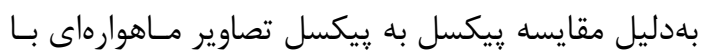
يكديخر، اين تصاوير بايد كاملاً ازنظر هندسى بر يكديخر منطبق باشند. بههمين دليل قبل از شروع :بردازشهـا و

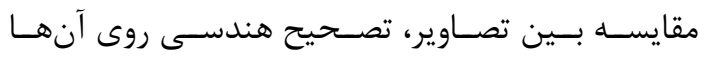

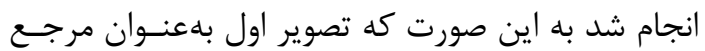

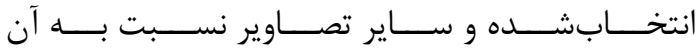
تصحيح گرديدند. r-r-r- הيادهسازى الكوريتم

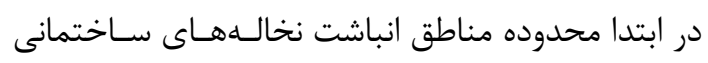

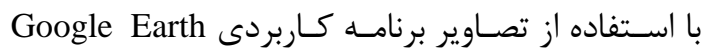
شناسايى و جهت اطمينان از صحت انتخاب، از منـاطق

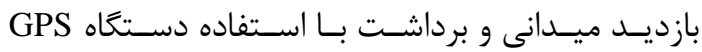

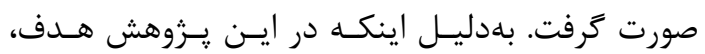
شناسايى مناطق انباشت نخالهها در حاشيه شهر اسـت، محدودهى منطقه شهرى و معادن ماسه كــه در منطقـهـ

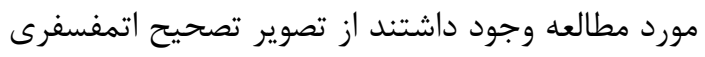
شده، ماسك شدند. يس از انجام مرحله ماسك، براى بلهدست آوردن شـدت 
يوشش كَياهى در برمى گيرند جهت تعيين حسد آسـتانه

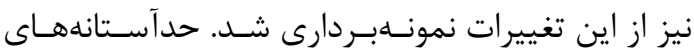

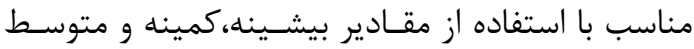
توابع تفاضلى يوششهاى مختلف در بانـدهاى مختلـف انتخاب شدند.

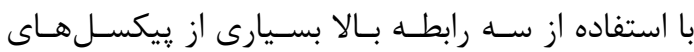
بدون تغيير و ويكسل هاى تغيير يافتهى يوشش كيـاهى

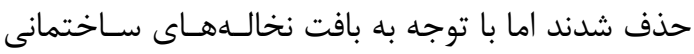

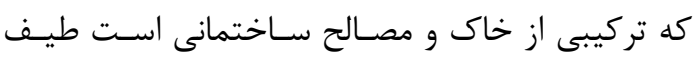

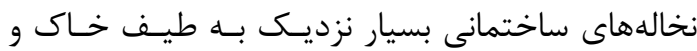
ساختمان خواهد بود و جالش اصلى در شناسايى اماكن

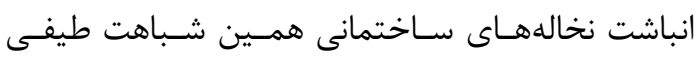

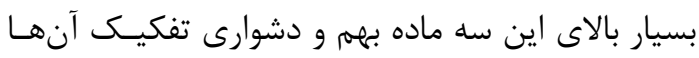

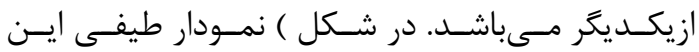

سه ماده در باندهاى مختلف تصوير رسم شده است.

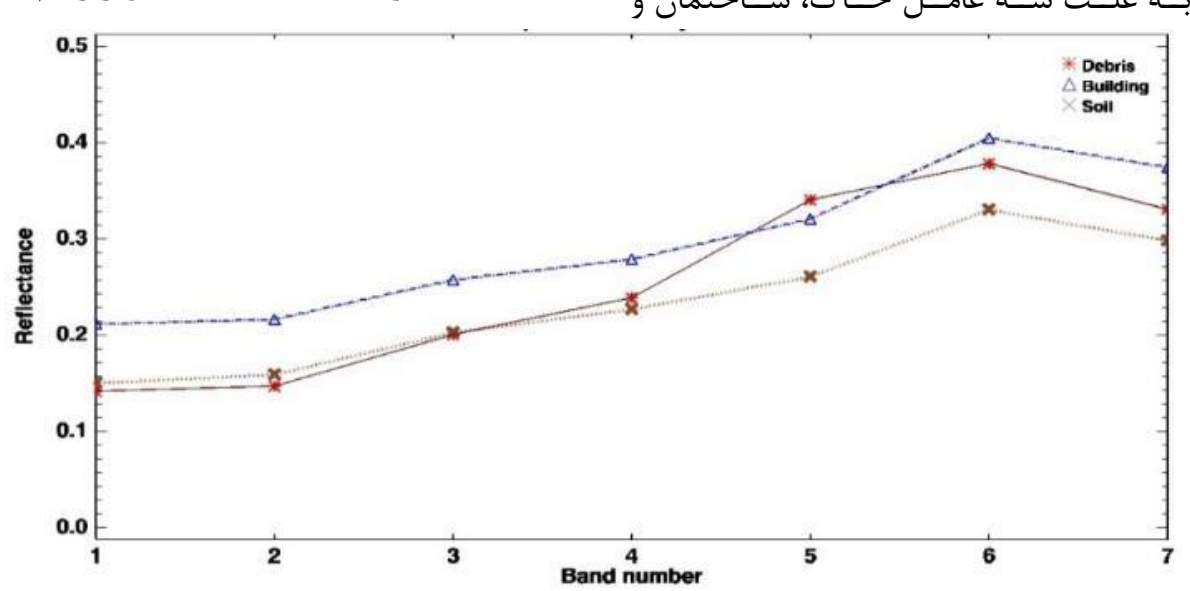

متنــاظر در تصـوير اول و دوم و ع مقـدار مثبـت بسـيار

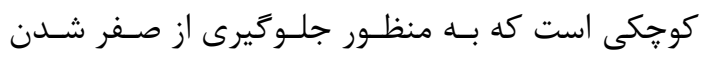

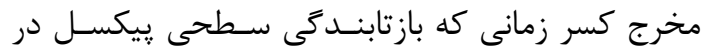
تصوير اول صفر است قرار كرفته، هستند.

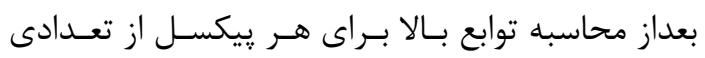

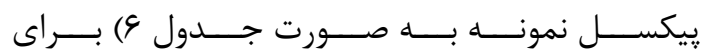
حدآستانه كذارى استفاده شد.

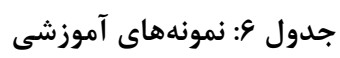

\begin{tabular}{|c|c|}
\hline تعداد ييكسل نمونه & نوع محدوده \\
\hline Tri & انباشت نخاله \\
\hline ITF. & خاك لخت \\
\hline fq. & ساختمان \\
\hline IITF & يوشش گياهى \\
\hline
\end{tabular}

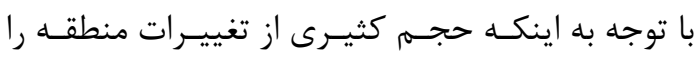

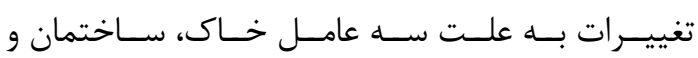

شكل F: نمودار باز تابندكى طيفى سه يوشش سطحى خاك، سـ

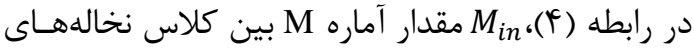
بــهـ همـين منظــور بــراى حــذف تغييـرات سـطحى سـاختمانى و كـلاس nlم در بانســ i ،

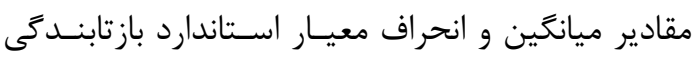

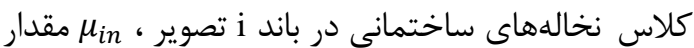
ميانكَين مقادير بازتابندكى كلاس nام در باند i تصوير و

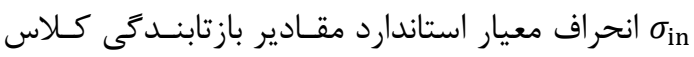

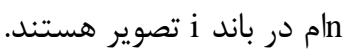

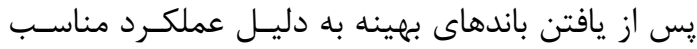

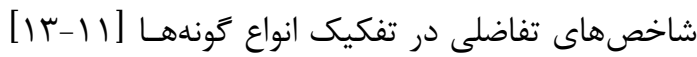

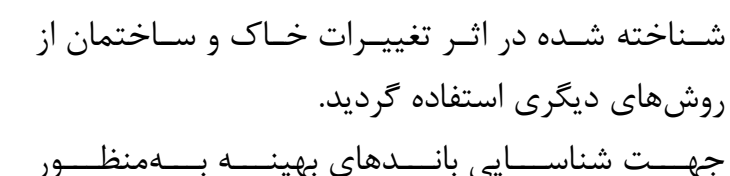

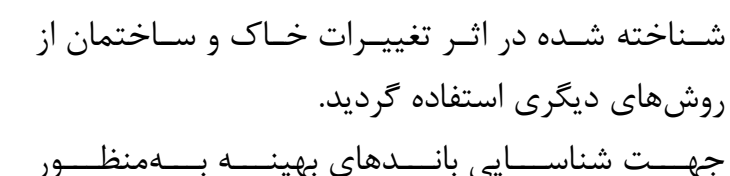

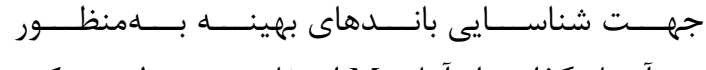

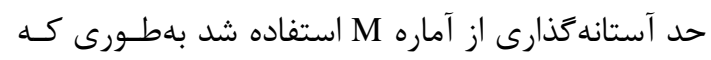

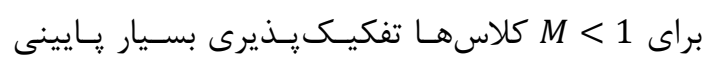

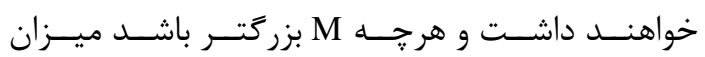
تفكيكيذيرى كلاسها بيشتر خواهد بود [ • 1].

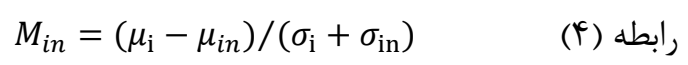


نخالههاى ساختمانى است و با فرض اينكـهـ ايـن امـاكن

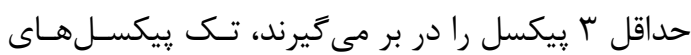

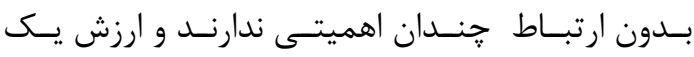

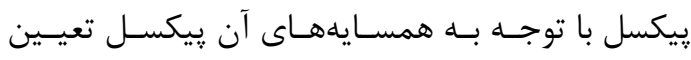

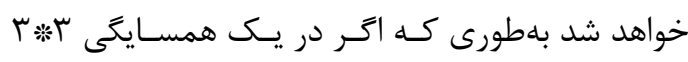

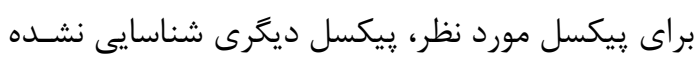

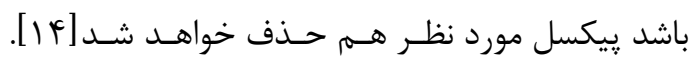

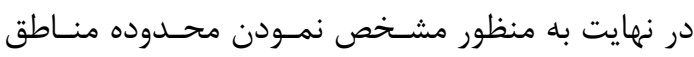

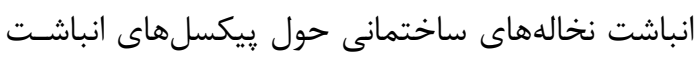
شناسايى شده بافر زده شده است.

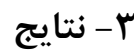

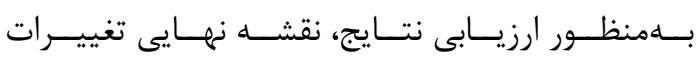

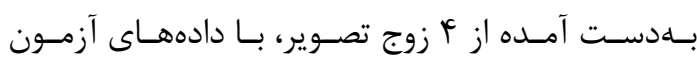

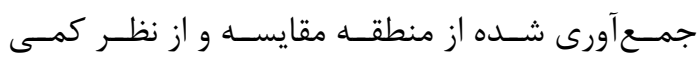

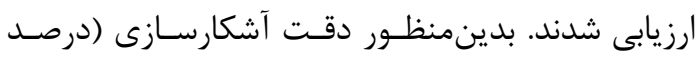

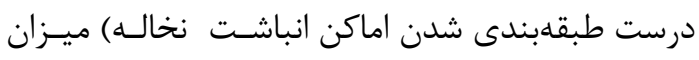

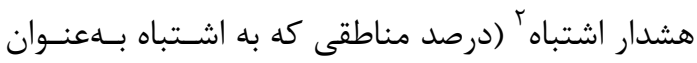

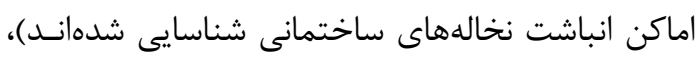

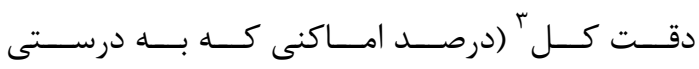
طبقهبندى شدهاند.) ميزان خطاى كل (درصد منـاطقى (درصى كه اشتباه شناسايى شدهاند) محاسبه شد. شدان

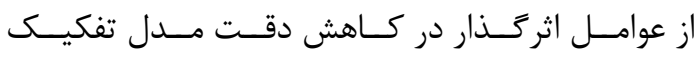

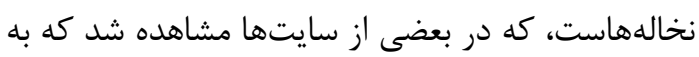

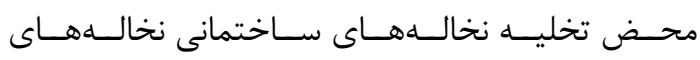

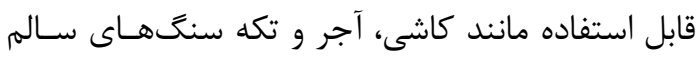

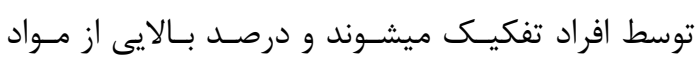

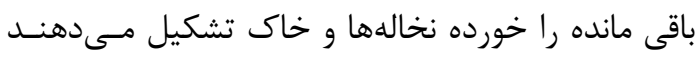

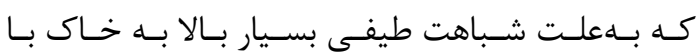

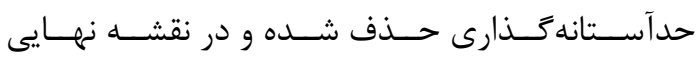

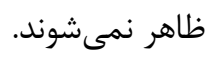

\footnotetext{
${ }^{2}$ False Alarm Rate

${ }^{3}$ Overall Accuracy
}

با استفاده از شاخصهاى تفاضلى بهنجار شده نخالههاى

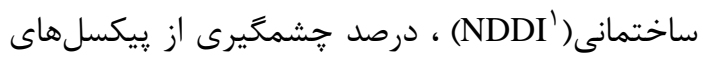

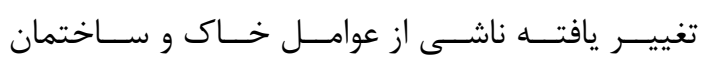

$$
N D D I=\frac{I_{6}(x, y)-I_{3}(x, y)}{I_{6}(x, y)+I_{3}(x, y)}
$$
حذف شدند.

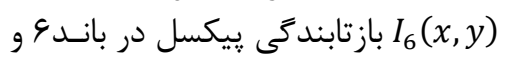

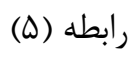

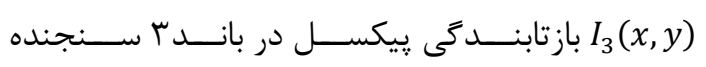

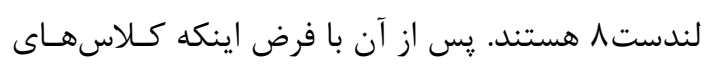

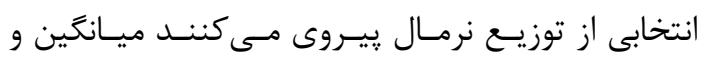

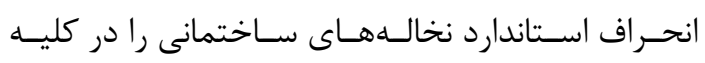

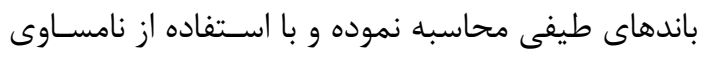

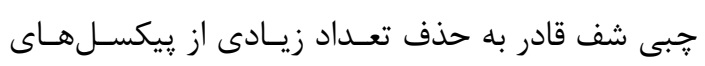

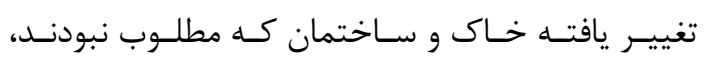

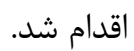

$$
\begin{aligned}
& \left(I_{i}(x, y)-\mu_{i}\right)^{2} \geq k^{2} \sigma_{i}^{2} \\
& \text { رابطه (ع) }
\end{aligned}
$$

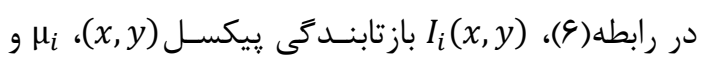

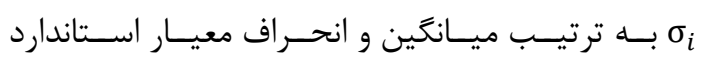
باز تابندكى نخاله هاى ساختمانى در باندأ تصوير هستند.

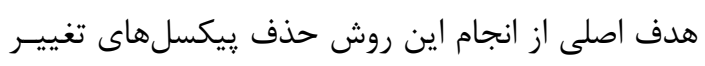

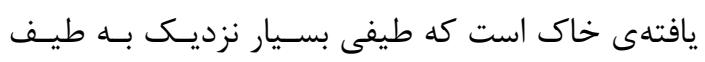

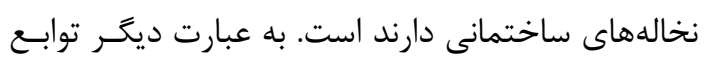

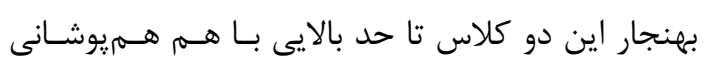

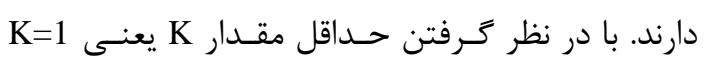

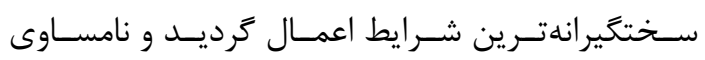

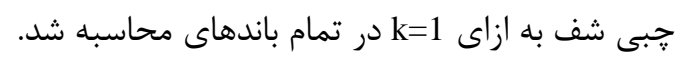

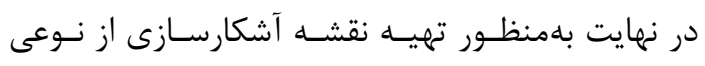

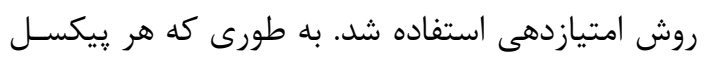

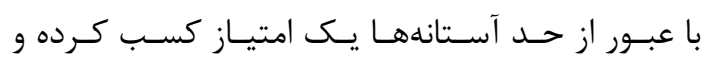

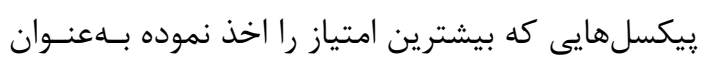

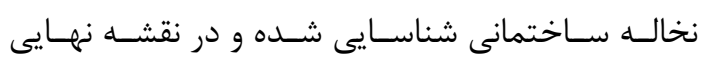

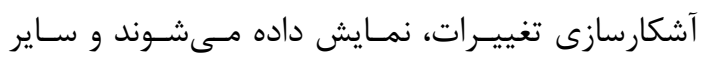
ريكسل ها حذف ترديدند.

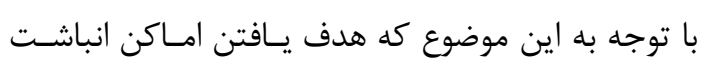

\footnotetext{
${ }^{1}$ Normalized difference debris index
} 


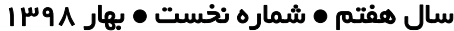
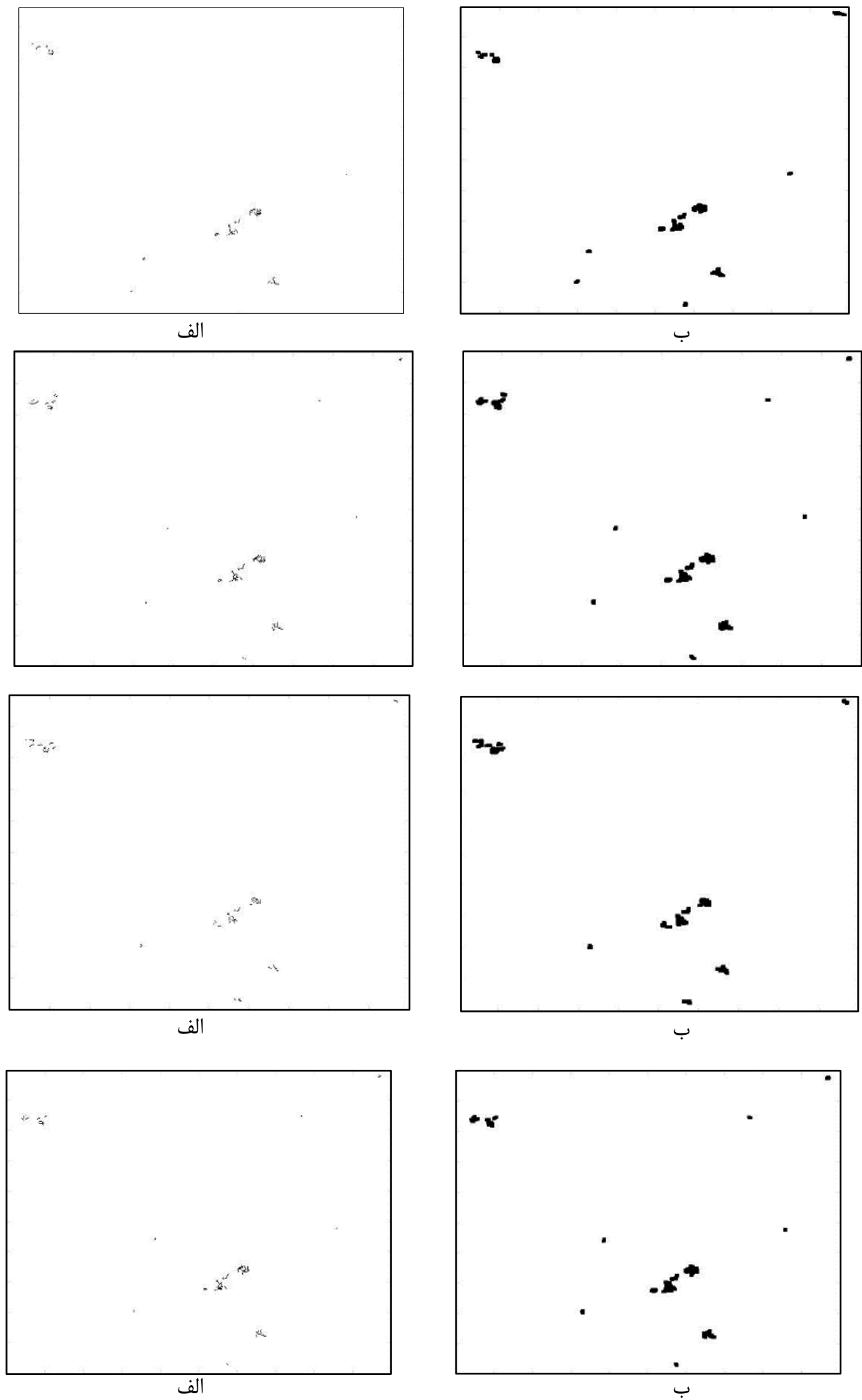

شكل ه: نقشه اماكن انباشت نخالههاى ساختمانى باستفاده از fزوج تصوير.(الف:ييكسلهاى شناسايى شده. ب: محدوده بافرزه شده ) 


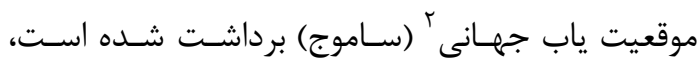

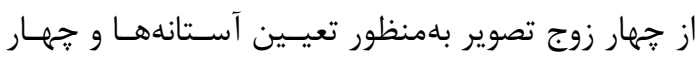

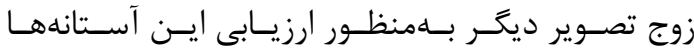

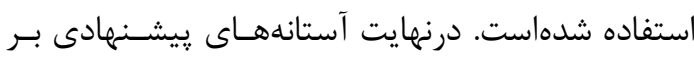

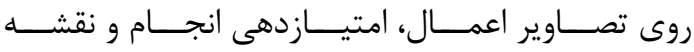

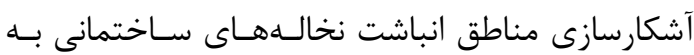
دست آمد. در نهايت هم با اسـتفاده از تصـاوير آزمـون، آنسان

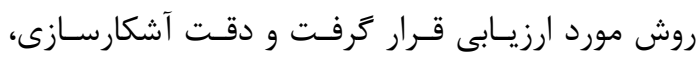
نرخ هشدار، دقت كل و خطاى كل بر آورد كرديد.

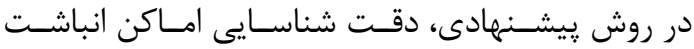

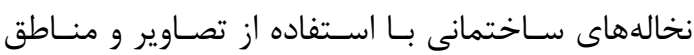

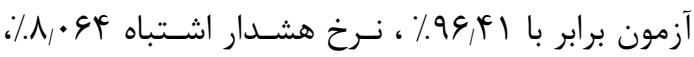

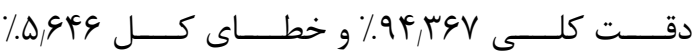

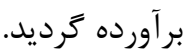

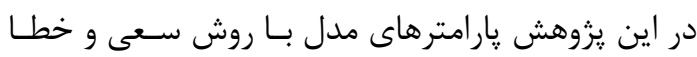

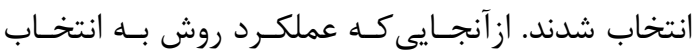
مناسب يارامترهاى آن وابسته است، تحقيـق بيشـتر در

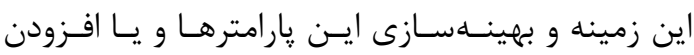

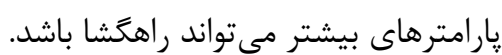

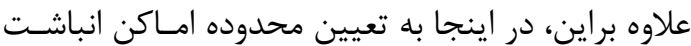

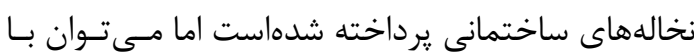

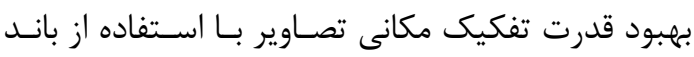

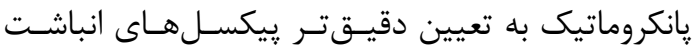

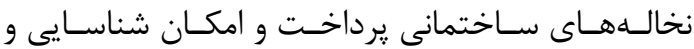
تعيين كونهاى مختلف نخاله هاى سـاختمانى و مقــــار

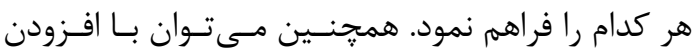

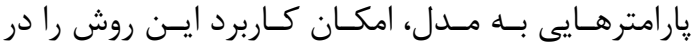
شناسايى نخالههاى انباشت شده در نواحى شهرى نيـز

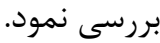

\footnotetext{
${ }^{2}$ Global Positioning System (GPS)
}

\section{F - ارائه نتايج و يِيشنهادها}

آشكارسازى و شناسـايى تغيــرات يكى از كاربردهـاى عمده سنجشازدور است. با استفاده از ويزگكى تكـرار در برداشت دادههاى دورسنجى زمانهاى مختلـف، امكـان

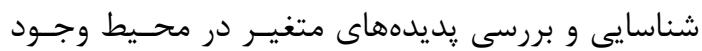

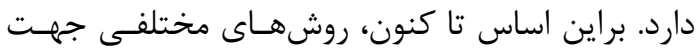

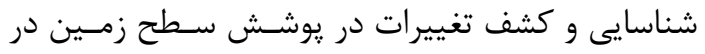
سنجش از دور توسعه داده شده است.

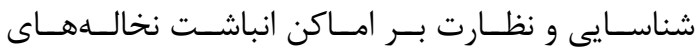

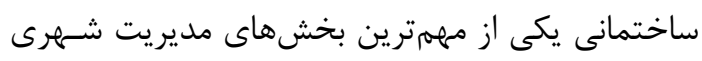

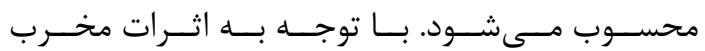

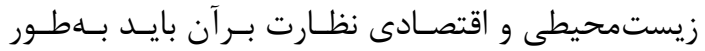

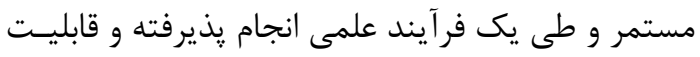
تكنولوزى سنجشازدور و هوشمندسازى روشها ئندا و يا به

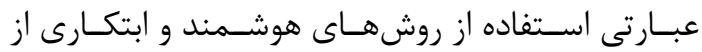

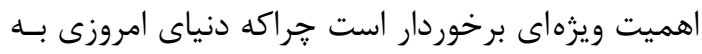
دنبال سرعت و دقت بالاتر است. در تحقيق حاضر شناسـايى امـاكن انباشـت نخالـهـــاى ساختمانى اطراف شهرستان شهريار و ملارد با اسـتفاده

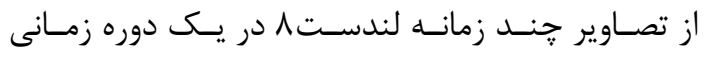
موردبررسى قرارگرفته است. بهمنظور آشكارسازى تغييرات شش تصوير קند طيفى

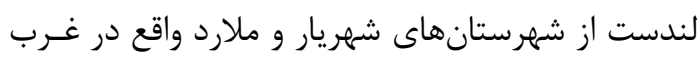

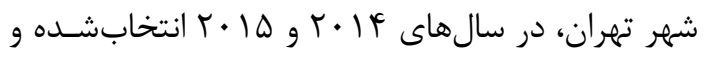
يس از انجام تصحيحات اتمسفرى، تصـوير آشكارسـازى دئ اوليه از طريق اعمال توابع تفاضلى بر مقادير بازتابندكى

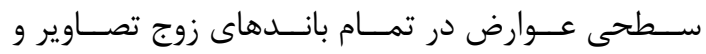

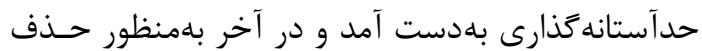

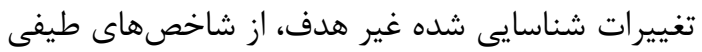
استفاده شد. محدودهى انباشت نخالهها از طريق بازئ إنديد

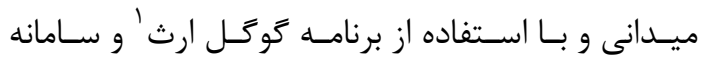

\footnotetext{
${ }^{1}$ Google Earth
} 
[1] P.V. Gorserski, K. R. Donerska, and C. D. Mitrorski, "Evaluation techniques with geographic information systems for landfill site selection: A case study using ordered weighted average.", Waste Management. Integrating multi-Criteria,Vol.21, pp. 858868, 2012.

[2] S. P. Gbanie, P. B. Tengbe, J. S. Momoh, J. Medo, and V. T. S. Kabba, "Modelling Land Fill Location Using Geographies Information Systems (GIS) and MultiCriteria Deosion Analysis (MCDA): Case Study Bo, Southern Sierraleone", Applied Geography, vol.36, pp. 3-12, 2013.

[3] K. Nabil, A. Nayef, A. Ibrahim, and A. Jasem, "Environmental Management of Construction and demolition waste in Kuwait." Waste Management, vol.24, pp. 1049-1059, 2004.

[4] Municipalities Organization, Executive style organization development and construction debries. (persian), 2012

[5] A. Singh, "Digital change detection techniques using remotely-sensed data." International Journal of Remote sensing, vol.10, pp. 989-1003, 1989.

[6] B. Quinlan, C. Huybrects, C. Schmidt, and J. W. Skiles, "Detecting Waste Tire Piles Using High-Resolution Satellite”. peresented at ASPRS Annual Conference, Reno, Nevada, 2006.

[7] G. M. Beavers, "Utilization of Low Altitude Remote Sensing to Detect Larval Habitats of Tire-Breeding Mosquitoes." $\mathrm{PhD}$ Dissertation, University of Kentucky, 1996.

[8] R. T. Eguchi, C. K. Huyck, B. J. Adams, B. Mansouri, B. Houshmand, and M. Shinozuka, "Resilient Disaster Response:
Using Remote Sensing Technologies for Post-Earthquake Damage Detection." Multidisciplinary Center for Earthquake Engineering Research (MCEER), 2003.

[9] M. H. Kesikoglu, U. H. Atasever, and C. Ozkan, "Unsupervised change detection in satellite images using fuzzy c-means clustering and principal component analysis.", International Archives of the Photogrammetry, Remote Sensing and Spatial Information Sciences, Antalya, Turkey, 2013.

[10] Y. J. Kaufman, and L. A. Remer, "Detection of forests using mid-IR reflectance: an application for aerosol studies.", IEEE Transactions on Geoscience and Remote Sensing, vol.32, pp. 672-683, 1994.

[11]A. Abd.Rahman, S.A. I Wayan, A. I Wayan, and N. I Wayan, "Enhanced Built-Up and Bareness Index (EBBI) for Mapping BuiltUp and Bare Land in an Urban Area." Remote Sensing, vol.4: pp. 2957-297, 2012

[12]D. Lu, Mausel, P. Brondzio, E. and E. Moran, "Change detection techniques", International Journal of Remote sensing, vol.25: pp. 2365-2407, 2007

[13] W. J. Todd, "Urban and regional land use change detected by using Landsat data." Jurnal of Research by the US Geological Survey, vol.5, pp. 527-534, 1977.

[14] R. M. Haralick, S. R. Sternberg, and X. Zhuang, "Image Analysis Using Mathematical Morphology.", IEEE Transactions on Pattern Analysis And Machine Intelligence, vol.9, pp. 532-550, 1987. 


\title{
Detection of construction debris dumping sites using Landsat images (Case study: Shahriar and Mallard districts)
}

Mohammad Reza Mobasheri ${ }^{* 1}$, Narges Jafari ${ }^{2}$

1- Professor, Remote sensing Dept., Khavaran Institute of Higher Education, Mashhad, Iran

2- MSc. student, Remote sensing Dept., K.N Toosi University of Technology, Tehran, Iran.

\begin{abstract}
Natural phenomena and human activities are always changing the earth and Knowing about changad information of the earth's surface is becoming more and more important in monitoring the local, regional and global resources and environments. The large collection of past and present remote sensing images made it possible to analyze spatio-temporal pattern of environmental elements and impacts of human activities in past decades. Meanwhile the modern world needs accurate information about these changes for updating Geospatial Information Systems(GIS) and databases. Detecting and monitoring waste sites is one of the most essential parts of urban management and due to the impact of environmental and economic issues for these sites, they must be monitored continuously and in a scientific manner. In this study, detecting the construction debris around Shahryar during a period of time is studied. In this study, images of 2014 and 2015 Landsat8 are used. In this method, and after some pre-processing, using image differencing and spectral indices, change detection map is produced. The overall accuracy of the proposed method was of the order of $96.41 \%$.
\end{abstract}

Key words: Change Detection, Construction Debris, Remote Sensing, Landsat8. 